\title{
PENERAPAN PRINSIP CITIZEN'S CHARTER PADA DINAS PENANAMAN MODAL DAN PELAYANAN TERPADU SATU PINTU KABUPATEN GOWA
}

\section{APPLICATION OF CITIZEN'S CHARTER PRINCIPLE IN DINAS OF INVESTMENT AND INTEGRATED SERVICES ONE DOOR IN GOWA REGENCY}

\author{
Renny Puteri Harapan Rani ${ }^{1}$, Amir Imbaruddin ${ }^{2}$, dan Muttaqin ${ }^{3}$ \\ ${ }^{1}$ Sekretariat Daerah Kabupaten Gowa \\ email: rennyranirasyid@gmail.com \\ ${ }^{2}$ STIA LAN Makassar \\ email: aimbaruddin@yahoo.com \\ ${ }^{3}$ STIA LAN Makassar \\ email: muttaqin_lan@yahoo.com
}

\begin{abstract}
Abstrak
Tujuan penelitian ini adalah untuk mengetahui dan menganalisis penerapan prinsip citizen's charter pada Dinas Penanaman Modal dan Pelayanan Terpadu Satu Pintu Kabupaten Gowa. Metode penelitian yang digunakan adalah metode kualitatif. Teknik pengumpulan data melalui wawancara, observasi dan telaah dokumen. Informan penelitian sebanyak 12 orang, yang terdiri dari Kepala Dinas 1 orang, Kepala Bidang 2 orang, Kepala Seksi 4 orang, dan Penerima Layanan Perizinan dan Non Perizinan 6 orang. Prosedur pengolahan dan analisis data adalah analisis kualitatif yang dilakukan melalui lima tahapan yaitu tahap pengumpulan data, reduksi data, display data, verifikasi data, dan penarikan kesimpulan. Hasil penelitian menunjukkan bahwa DPM PTSP Kabupaten Gowa belum sepenuhnya menerapkan prinsip citizen's charter sebagaiamana teori Oliver dan Drewry, yakni standar pelayanan yang tinggi (higher standard), keterbukaan (openness) pelayanan, informasi (information) pelayanan, tidak diskriminasi (non discrimination) pelayanan, daya respon (responsiveness) pelayanan, keluhan (grievances) pelayanan, karena belum ada kerjasama dengan lembaga pengawasan independen dan tanda charter (petunjuk arah) pelayanan; belum ada publikasi struktur organisasi lengkap dengan nama-nama pejabat yang berwenang dan publikasi biaya pelayanan secara munual dan daring; belum ada publikasi informasi target kinerja dan capaian pelaksanaan kinerja secara daring; belum memiliki peraturan mengenai jaminan kesamaan hak bagi penerima layanan; belum adanya permintaan tanggapan penerima layanan oleh pegawai atas
\end{abstract}


pelayanan yang diberikan; belum adanya kerjasama dengan lembaga independen sebagai mediator antara pihak DPM-PTSP Kabupaten Gowa dengan penerima layanan apabila tidak terjadi kesepakatan penyelesaian keluhan atau pengaduan.

Kata Kunci: Prinsip Citizen’s Charter; Pelayanan Perizinan, Kualitas Pelayanan Perizinan.

\begin{abstract}
The purpose of this research is to know and analyze the application of citizen's charter principle to the Department of Investment and One Stop Service of Gowa Regency. The research method used is qualitative method. Data collection techniques through interviews, observation and document review. The research informants are 12 people, consisting of Head of Service 1 person, Head of Division 2 persons, Head of Section 4 person, and Service Licensing and Non Licensee 6 people. Processing and data analysis is a qualitative analysis conducted through five stages of data collection, data reduction, data display, data verification, and conclusion. The results show that DPM PTSP Gowa Regency has not fully applied the principle of citizen's charter as the theory of Oliver and Drewry, namely higher service standard, service openness, service information, non-discrimination service, service responsiveness, service grievances, as there is no cooperation with independent oversight agencies and charter signatures (directions) of service; there is no publication of the complete organizational structure with the names of authorized officials and the publication of the cost of services in a munual and online manner; no publication of performance target information and performance performance achievements online; does not yet have a regulation on guarantee of equal rights for the beneficiaries; the absence of requests for service recipient response by the employee for the services provided; the absence of cooperation with independent institutions as mediator between the DPM-PTSP Gowa District with the recipient of service in the event of no agreement on the settlement of complaints or complaints.
\end{abstract}

Keywords: Principles of Citizen's Charter, Licensing Service, Quality of Licensing Services.

PENDAHULUAN

Pendekatan baru untuk melibatkan warga dan stakeholders dalam penyelenggaraan pelayanan publik telah dilakukan melalui maklumat pelayanan atau kontrak pelayanan. Kementerian
Pendayagunaan Aparatur Negara (Menpan) mengadopsi citizen's charter dengan mengembangkan maklumat pelayanan, yaitu menetapkan suatu janji dari penyelenggara kepada pengguna tentang bagaimana pelayanan akan diselenggarakan. Sebagai 
sebuah janji, maklumat dibuat oleh penyelenggara tanpa melibatkan para pengguna atau pemangku kepentingan. Sedangkan seharusnya kita menerapkan kontrak pelayanan, yang merupakan hasil kesepakatan antara birokrasi pelayanan dengan warga pengguna dan para pihak yang berkepentingan lainnya tentang pelayanan apa yang akan diberikan, waktu, biaya, dan cara penyelenggaraannya.

Citizen's charter sebagai suatu pendekatan dalam penyelenggaraan pelayanan publik yang menempatkan pengguna layanan sebagai pusat pelayanan. Artinya kebutuhan dan kepentingan pengguna layanan harus menjadi pertimbangan utama dalam keseluruhan proses penyelenggaraan pelayanan publik.

Citizen's charter mendorong penyedia layanan untuk bersama dengan pengguna layanan dan pihak-pihak yang berkepentingan (stakeholders) lainnya untuk menyepakati jenis, prosedur, waktu, biaya, serta cara pelayanan. Kesepakatan tersebut harus mempertimbangkan keseimbangan hak dan kewajiban antara penyedia layanan, pengguna layanan, serta stakeholders. Kesepakatan ini nantinya akan menjadi dasar praktek penyelenggaraan pelayanan publik.
Citizen's charter diperlukan karena beberapa hal. Pertama, untuk memberikan kepastian pelayanan yang meliputi waktu, biaya, prosedur, dan cara pelayanan. Kedua, pemberian informasi mengenai hak dan kewajiban pengguna layanan, penyedia layanan, dan stakeholder lainnya dalam keseluruhan proses penyelenggaraan pelayanan. Ketiga, untuk mempermudah pengguna layanan, warga, dan stakeholder lainnya dalam mengontrol praktik penyelenggaraan pelayanan. Keempat, untuk mempermudah manajemen pelayanan memperbaiki kinerja penyelenggaraan pelayanan. Kelima, untuk membantu manajemen pelayanan mengidentifikasi kebutuhan, harapan, dan aspirasi pengguna layanan serta stakeholder lainnya.

Dalam rangka meningkatkan kualitas pelayanan perizinan dan non perizinan di Kabupaten Gowa, maka dibentuk Kantor Dinas Penanaman Modal dan Pelayanan Terpadu Satu Pintu Kabupaten Gowa berdasarkan Perda Kabupaten Gowa Nomor 11 Tahun 2016, kemudian untuk menjalankan pelayanan perizinan maka dikeluarkan Peraturan Bupati Nomor 60 Tahun 2017. Dengan dibentuknya DPM PTSP Kabupaten Gowa diharapkan dapat meningkatkan kualitas pelayanan perizinan dan non perizinan sehingga terwujud 
pelayanan publik yang cepat, murah, mudah, transparan, pasti dan terjangkau.

Penerapan pelayanan perizinan dan non perizinan di DPM PTSP Kabupaten Gowa belum terimplementasi dengan baik karena rendahnya kemampuan petugas dalam pengelolaan informasi yang efektif dengan minim publikasi informasi pelayanan, baik dalam bentuk pengumuman, maupun dalam bentuk daring, keterbatasan akses informasi prosedur dan mekanisme pelayanan. Data pada website DPM PTSP Kabupaten Gowa bahwa informasi tidak dimuat alur pelayanan, hanya dimuat mengenai persyaratan administrasi masingmasing pelayanan perizinan. Selain itu mekanime sistem pengawasan internal bagi pegawai tidak jelas.

Secara konseptual bahwa citizen's charter merupakan suatu terobosan baru dalam meningkatkan pelayanan, namun dalam penerapan pelayanan perizinan dan non perizinan pada DPM PTSP Kabupaten Gowa menuai banyak permasalahan sehingga berimbas terhadap pelayanan yang diterima penerima layanan. Berangkat dari permasalahan tersebut di atas maka tujuan penelitian ini adalah untuk mengetahui dan menganalisis penerapan prinsip citizen's charter pada Dinas Penanaman Modal dan
Pelayanan Terpadu Satu Pintu Kabupaten Gowa.

\section{METODE PENELITIAN}

Metode penelitian yang digunakan adalah metode kualitatif. Teknik pengumpulan data melalui wawancara, observasi dan telaah dokumen. Informan penelitian sebanyak 12 orang, yang terdiri dari Kepala Dinas 1 orang, Kepala Bidang 2 orang, Kepala Seksi 4 orang, dan Penerima Layanan Perizinan dan Non Perizinan 6 orang. Prosedur pengolahan dan analisis data adalah analisis kualitatif yang dilakukan melalui lima tahapan yaitu tahap pengumpulan data, reduksi data, display data, verifikasi data, dan penarikan kesimpulan.

\section{HASIL PENELITIAN}

Fokus penelitian ini adalah standar pelayanan yang tinggi (higher standard), keterbukaan (openness), informasi (information), tidak diskriminasi (non discrimination), daya respon (responsiveness), keluhan (grievances) pada DPM PTSP Kabupaten Gowa sebagai berikut:

\section{Standar yang Tinggi Pelayanan}

Standar pelayanan yang tinggi pada DPM PTSP Kabupaten Gowa di lihat dari proses penetapan standar pelayanan, 
cakupan standar pelayanan, dan penerapan standar pelayanan. Hasil wawancara informan penelitian mengenai proses penetapan standar pelayanan memberikan gambaran bahwa proses penetapan standar pelayanan yang diterapkan telah melalui serangkaian tahapan, mulai dari studi banding, kemudian dirapatkan kembali. Hasil rapat penetapan standar pelayanan dan SOP pelayanan kemudian serahkan kepada Kantor Bupati Bagian Hukum untuk memperoleh persetujuan dan registrasi peraturan, setelah itu di bawa kepada Bupati untuk mendapat ditandatangani. Adapun jenis pelayanan Berdasarkan Surat Keputusan Bupati Gowa Nomor 189/IV/2011 tentang Pelimpahan Kewenangan Pengelolaan Perizinan adalah :

Tabel 1

Jenis Pelayanan Perizinan pada DPM PTSP Kabupaten Gowa

\begin{tabular}{|c|c|}
\hline No & Jenis Izin \\
\hline 1 & Izin Prinsip \\
\hline 2 & Izin Lokasi \\
\hline 3 & Tanda Daftar Industri \\
\hline 4 & Surat Izin Tempat Usaha \\
\hline 5 & Izin Ganguan \\
\hline 6 & Izin Mendirikan Bangunan \\
\hline 7 & Izin Kelayakan Lingkungan \\
\hline 8 & Surat Izin Usaha Perdangangan \\
\hline 9 & Tanda Daftar Perusahaan \\
\hline 10 & Tanda Daftar Gudang \\
\hline 11 & Surat Izin Usaha Industri \\
\hline 12 & $\begin{array}{l}\text { Izin Kesehatan terdiri dari : Surat Izin Klinik, Perpanjangan } \\
\text { Izin Klinik, Sertifikat Produksi Pangan Industri Rumah } \\
\text { Tangga, Surat Izin Praktek Dokter Umum, Gigi, Spesialis, } \\
\text { Surat Izin Praktek Bidan, Izin Apotik, Izin Toko Obat, } \\
\text { Izin Kerja Tenaga Teknis Kefarmasian, Surat Terdaftar } \\
\text { Pengobat Tradisional }\end{array}$ \\
\hline 13 & Izin Usaha Jasa Konstruksi \\
\hline 14 & Izin Usaha Pariwisata \\
\hline 15 & Pelayanan Non Perizinan, yaitu Reklame \\
\hline
\end{tabular}

Selanjutnya hasil wawancara informan penelitian mengenai cakupan standar pelayanan memberikan gambaran bahwa standar pelayanan dan SOP masing jenis pelayanan yang telah ditetapkan belum mencakup seluruh komponen pada setiap jenis pelayanan. Sesuai dengan Perda Kabupaten Gowa Nomor 11 Tahun 2016, maka ditetapkan mekanisme/alur pelayanan, yakni proses perizinan dengan rekomendasi (non usaha), proses perizinan dengan rekomendasi dan tinjauan lapangan (usaha), dan proses perizinan tanpa rekomendasi dan tinjauan lapangan.

Berdasarkan data yang diperoleh pada DPM PTSP Kabupaten Gowa mengenai biaya layanan bahwa dari 15 jenis pelayanan tidak dikenakan retribusi kecuali Izin Mendirikan Bangunan (IMB) dan Pajak Reklame. Untuk lebih jelasnya dapat di lihat pada tabel di bawah ini :

Tabel 2

Biaya Pelayanan Perizinan DPM PTSP Kabupaten Gowa Tahun 2018

\begin{tabular}{|c|l|c|}
\hline No & \multicolumn{1}{|c|}{ Jenis Izin } & Biaya Pelayanan \\
\hline 1 & Izin Prinsip & Tidak dikenakan retribusi \\
\hline 2 & Izin Lokasi & Tidak dikenakan retribusi \\
\hline 3 & Tanda Daftar Industri & Tidak dikenakan retribusi \\
\hline 4 & Surat Izin Tempat Usaha & Tidak dikenakan retribusi \\
\hline 5 & Izin Ganguan & Tidak dikenakan retribusi \\
\hline 6 & Izin Mendirikan Bangunan & Dikenakan Retribusi \\
\hline 7 & Izin Kelayakan Lingkungan & Tidak dikenakan retribusi \\
\hline 8 & $\begin{array}{l}\text { Surat Izin Usaha } \\
\text { Perdangangan }\end{array}$ & Tidak dikenakan retribusi \\
\hline 9 & Tanda Daftar Perusahaan & Tidak dikenakan retribusi \\
\hline 10 & Tanda Daftar Gudang & Tidak dikenakan retribusi \\
\hline 11 & Surat Izin Usaha Industri & Tidak dikenakan retribusi \\
\hline 12 & Izin Kesehatan & Tidak dikenakan retribusi \\
\hline 13 & Izin Usaha Jasa Konstruksi & Tidak dikenakan retribusi \\
\hline
\end{tabular}




\begin{tabular}{|c|l|c|}
\hline 14 & Izin Usaha Pariwisata & Tidak dikenakan retribusi \\
\hline 15 & $\begin{array}{l}\text { Pelayanan Non Perizinan, } \\
\text { yaitu Reklame }\end{array}$ & Dikenekanan Retribusi \\
\hline
\end{tabular}

Sesuai dengan Permendagri Nomor 138 Tahun 2017 bahwa DPM PTSP Kabupaten Gowa melakukan pengawasan secara internal yang dilakukan langsung oleh Kepala Dinas, sedangkan pengawasan secara eksternal belum melakukan kontrak kerjasama dengan lembaga pengawasan independen. Pengawasan eksternal yang dilakukan langsung oleh BPK dan KPK terkait kesesuaian pelaksanaan pelayanan dengan standar pelayanan yang telah ditetapkan.

Standar pelayanan yang telah ditetapkan belum memenuhi cakupan standar pelayanan yang dibutuhkan, seperti yang disebutkan dalam Permendagri Nomor 138 Tahun 2017. Cakupan standar pelayanan pada DPM PTSP Kabupaten Gowa, yakni dasar hukum; persyaratan; sistem, mekanisme, dan prosedur; jangka waktu penyelesaian; biaya/tarif; produk pelayanan; sarana, prasarana, dan/atau fasilitas; penanganan pengaduan, saran, dan masukan, sistem pengawasan internal, namun belum memiliki jaminan kepastian pelayanan, kerjasama lembaga pengawasan independen, dan evaluasi pelayanan perizinan. Sedangkan SOP pelayanan telah memenuhi cakupan standar pelayanan yang dibutuhkan.

Selanjutnya hasil wawancara informan penelitian mengenai penerapan standar pelayanan memberikan gambaran bahwa penerapan standar prosedur pelayanan yang berlaku telah berjalan dengan baik. Pada tahun 2017 DPM PTSP Kabupaten Gowa telah mengeluarkan 29 jenis izin dengan jumlah pemohon sebanyak 10.976 sama dengan jumlah izin yang diterbitkan, yakni 10.976 atau realiasi penerbitan izin 100 persen. Sedangkan realisasi penerimaan PAD tahun 2017 mencapai 91,91 persen dari target PAD. Penerapan standar pelayanan perizinan sangat baik di lihat dari jumlah pelayanan perizinan yang diajukan penerima layanan terselesaikan dan penerimaan retribusi perizinan mengalami peningkatan yang cukup signifikan dari tahun sebelumnya.

\section{Keterbukaan Pelayanan}

Ketebukaan pelayanan pada DPM PTSP Kabupaten Gowa di lihat dari keterbukaan publikasi tatanan organisasi, keterbukaan biaya, mekanisme/alur, visi misi, motto, dan Jadwal/waktu pelayanan. Hasil wawancara informan penelitian mengenai kejelasan tatanan struktur organisasi memberikan gambaran bahwa 
kejelasan tatanan organisasi DPM PTSP Kabupaten Gowa cukup jelas, yakni terdapat struktur organisasi secara umum dan struktur organisasi tiap masing-masing bidang. Sedangkan mengenai kejelasan struktur organisasi telah tercantum dalam Perda Kabupaten Gowa Nomor 11 Tahun 2016. Tatanan organisasi DPM PTSP Kabupaten Gowa sangat jelas dengan struktur organisasi yang terdiri dari Kepala Dinas dengan dibantu seorang Sekretaris, 4 (empat) orang Kepala Bidang, 12 (dua belas) Kepala Seksi, dan 3 (tiga) Kepala Sub Bagian. Akan tetapi struktur organisasi tersebut belum terpasang pada ruang pelayanan.

Selanjutnya hasil wawancara informan penelitian mengenai keterbukaan biaya layanan memberikan gambaran bahwa keterbukaan biaya pelayanan telah dipublikasikan, namun bersifat internal dan terbatas. Publikasi biaya layanan belum diiformasikan di website, ruang pelayanan, brosur. Pada tahun 2017, Izin Ganguan, Izin Mendirikan Bangunan Pajak Reklame masih dikenakan retribusi, kemudian pada Tahun 2018 tidak dikenakan retribusi kecuali Izin Mendirikan Bangunan dan Pajak Reklame.

Kemudian hasil wawancara informan penelitian memberikan gambaran bahwa keterbukaan informasi yang diberikan kepada penerima layanan cukup bagus. Pada ruang pelayanan terpasang papan informasi terkait mekanisme/alur pelayanan dan pegawai cukup terbuka dalam memberikan informasi yang dibutuhkan penerima layanan. Mekanisme/alur pelayanan DPM PTSP Kabupaten Gowa terpajang pada ruangan pelayanan, yakni proses pelayanan perizinan dengan rekomendasi (non usaha), proses perizinan dengan rekomendasi tinjauan lapangan (usaha), serta proses perizinan tanpa rekomendasi dan tinjauan lapangan. Mekanisme/alur perizinan tersebut sangat jelas.

Selanjutnya hasil wawancara informan penelitian memberikan gambaran bahwa keterbukaan publikasi tatanan struktur organisasi sangat jelas secara internal, namun belum dipublikasikan secara eksternal sebab tatanan struktur organisasi pada ruang pelayanan masih tatanan struktur organisasi lama, dan petugas menggunakan tanda pengenai serta publikasi visi misi dan motto pada ruang pelayanan. Sedangkan terkait Jadwal/waktu penyelesaian layanan tertera pada brosur, akan tetapi tidak terpajang pada ruang pelayanan sehingga penerima layanan tidak dapat mengetahui 
langsung sebelum di lihat di brosur yang tersedia.

\section{Informasi Pelayanan}

Informasi pelayanan pada DPM PTSP Kabupaten Gowa di lihat dari publikasi informasi transparansi akses informasi mengenai target kinerja dan hasil pelaksanaan kinerja pelayanan. Pada Tahun 2017 bahwa indikator kinerja dan target kinerja DPM PTSP Kabupaten Gowa termuat pada LAKIP 2017. capaian indikator kinerja pada tahun 2017 DPM PTSP Kabupaten Gowa dengan realisasi target kinerja sebesar 100 persen, yakni realisasi penyelesaian izin sebanyak 10.976 izin dari 10.976 pemohon dan realisasi jumlah pengaduan yang ditindaklanjuti sebanyak 12 kasus yang ditindaklanjuti dari 12 pengaduan yang masuk.

Hasil wawancara informan penelitian memberikan gambaran bahwa publikasi target kinerja dan hasil pelaksanaan kinerja pelayanan masih sebatas publikasi internal, yakni tercantum dalam buku LAKIP yang diterbitkan setiap tahun. Belum ada publikasi ekternal baik pada papan informasi pelayanan maupun pada saat kunjungan sosialisasi layanan ke seluruh kecamatan serta website.
Kemudian hasil wawancara informan penelitian memberikan gambaran bahwa transparansi akses informasi mengenai target kinerja dan pelaksanaan kinerja pelayanan belum bisa diakses secara langsung oleh penerima layanan, baik secara daring melalui website maupun secara langsung, berupa papan informasi pada kantor layanan perizinan. Akses informasi terkait target kinerja dan pelaksanaan dapat ditelusuri melalui website DPM-PTSP Kabupaten Gowa melalui www.dpmptsp.gowakab.go.id. Namun tidak ada publikasi terkait target kinerja yang terdapat pada LAKIP dan pelaksanaan kinerja berupa laporan kinerja pada website, hanya berupa visi, misi organisasi, struktur organisasi, tupoksi pegawai, persyaratan dan formulir pelayanan masing-masing jenis pelayanan, data informasi investasi, pengecekan status izin secara daring, dan pengaduan secara daring.

\section{Non Diskriminasi Pelayanan}

Non diskriminasi pelayanan pada DPM PTSP Kabupaten Gowa di lihat dari perlakukan pegawai terhadap penerima layanan dan jaminan kesamaan hak bagi penerima layanan. Hasil wawancara informan penelitian memberikan gambaran bahwa perlakukan pegawai terhadap penerima layanan sudah cukup baik. Setiap 
pegawai memberikan perhatian terhadap setiap penerima layanan, serta dilayani dengan baik dan cepat. Meskipun tetap ada perlakuan lebih apabila ada penerima layanan yang datang dan berstatus pejabat.

Selanjutnya hasil wawancara informan penelitian memberikan gambaran bahwa belum ada jaminan kesamaan hak pelayanan terhadap penerima layanan secara resmi dan tertulis. Namun secara internal Kepala Dinas memberikan instruksi lisan kepada seluruh pegawai bahwa wajib memberikan layanan yang sama terhadap seluruh penerima layanan.

\section{Daya Respon Pelayanan}

Daya respon pelayanan pada DPM PTSP Kabupaten Gowa di lihat dari tingkat respon pegawai, kepekaan dan kemampuan institusi pelayanan perizinan akan kebutuhan pelayanan. Hasil wawancara informan penelitian memberikan gambaran bahwa respon pegawai dalam memberikan pelayanan yang dibutuhkan penerima layanan cukup baik. Semua pegawai terutama pada front office kantor layanan perizinan langsung menyapa setiap penerima layanan yang datang dan menanyakan jenis layanan perizinan apa yang dibutuhkan. Pegawai menyampaikan kepada penerima layanan terkait dengan tata cara, persyaratan, dan prosedur pelayanan berdasarkan jenis pelayanan yang dibutuhkan penerima layanan.

Selanjutnya hasil wawancara informan penelitian memberikan gambaran bahwa kepekaan dan kemampuan institusi pelayanan perizinan akan kebutuhan pelayanan sudah bagus dengan tersedianya ruang tunggu yang nyaman bagi para penerima layanan, informasi pada papan struktur dan brosur yang memuat informasi pelayanan perizinan, tersedia loket pengaduan. Selain itu terdapat ruang konsultasi bagi penerima layanan serta penerima layanan dapat mengakses informasi pelayanan melalui website.

Pegawai cukup responsif dalam memberikan pelayanan dengan melayani penerima layanan sesuai antrian. Selain itu DPM PTSP Kabupaten Gowa memiliki kepekaan dan kemampuan untuk menyediakan prasarana pelayanan berupa ruangan pelayanan, loket informasi pelayanan, loket pengaduan, dan ruang tunggu pelayanan, dan ruang konsultasi pelayanan.

\section{Keluhan Pelayanan}

Daya respon pelayanan pada DPM PTSP Kabupaten Gowa di lihat dari jaminan 
kepastian penyelesaian masalah keluhan pelayanan dan respon pegawai terhadap keluhan pelayanan. Hasil wawancara informan penelitian memberikan gambaran bahwa jaminan kepastian penyelesaian masalah terhadap keluhan penggunan layanan belum ada secara resmi berupa regulasi tertulis. Akan tetapi semua bentuk pengaduan yang masuk pasti akan dilayani dan ditindaklanjuti hingga selesai serta semua bentuk keluhan dilaporkan dalam buku tahunan.

Selanjutnya hasil wawancara informan penelitian memberikan gambaran bahwa pegawai telah memberikan respon yang cepat dan cukup baik. Apabila ada penerima layanan yang melakukan pengaduan, akan dilakukan cek kelengkapan berkas dan kemudian menindaklajuti apabila ada keluhan.

Sarana pengaduan pada DPM PTSP Kabupaten Gowa berupa mekanisme pengaduan, kotak saran, hasil pengaduan masyarakat, brosur pengelolaan pengaduan. Selain itu pengaduan dapat dilakukan melalui telpon dengan nomor kontak 081343754199 dan melalui alamat email : dpmptspgowa@gmail.com. Pada Tahun 2017 jumlah dokumen pengaduan sebanyak 12 dokumen dan telah ditindaklanjuti melalui beberapa tindakan yaitu peninjauan lokasi, peninjauan kembali dokumen perizinan, dan koordinasi dengan lurah dan camat setempat dengan pengaduan yang ditindaklanjuti mencapai 100 persen.

\section{PEMBAHASAN}

\section{Standar yang Tinggi Pelayanan}

Menurut Oliver dan Drewry (1996) mengemukakan bahwa standar yang tinggi (higher standard) adalah adanya publikasi dengan bahasa yang jelas, standar pelayanan, pengawasan yang lebih kuat dan independen; menggunakan skema "tanda charter" untuk mengidentifikasi lembagalembaga yang ada melalui term charter. Sejalan dengan Undang-Undang Nomor 25 Tahun 2009 Pasal 1 Ayat (7) menyebutkan standar pelayanan adalah tolok ukur yang dipergunakan sebagai pedoman penyelenggaraan pelayanan dan acuan penilaian kualitas pelayanan sebagai kewajiban dan janji penyelenggara kepada masyarakat dalam rangka pelayanan yang berkualitas, cepat, mudah, terjangkau, dan terukur. Lebih lanjut Permendagri Nomor 138 Tahun 2017, Pasal 12 Ayat (1) menyebutkan bahwa dalam penyelenggaraan pelayanan perizinan dan non perizinan pemerintah daerah wajib menyusun, menetapkan, dan menerapkan, a) standar 
pelayanan; dan b) standar operasional prosedur.

Hasil penelitian Bilyastuti (2012) menunjukkan bahwa standar pelayanan yang diberlakukan berdasarkan kesepakatan bersama antara pihak rumah sakit dengan perwakilan unsur masyarakat pengguna layanan namun penerapan standar pelayanan ini belum berjalan secara optimal karena ada beberapa standar pelayanan yang masih belum memenuhi kesepakatan dalam dokumen citizen's charter diantaranya lama pelayanan seringkali melebihi waktu yang telah ditentukan.

Hasil penelitian menunjukkan bahwa DPM PTSP Kabupaten Gowa melakukan publikasi standar pelayanan dengan bahasa yang sangat jelas, standar pelayanan dan SOP pelayanan mencakup; persyaratan; sistem, mekanisme, dan prosedur; jangka waktu penyelesaian; biaya/tarif; produk pelayanan; sarana, prasarana, dan/atau fasilitas; pengawasan internal; penanganan pengaduan, saran, dan masukan. Akan tetapi belum dilakukan kerjasama dengan lembaga pengawasan independen untuk memperkuat pengawasan pelayanan dan belum ada tanda charter (petunjuk arah) pelayanan yang dapat memudahkan penerima layanan.

\section{Keterbukaan Pelayanan}

Menurut Oliver dan Drewry (1996) mengemukakan bahwa keterbukaan (openness) yaitu menghilangkan secrecy (kekaburan) tentang organisasional, biaya pelayanan, etc. : staff di identifikasi melalui nama-namanya. Sejalan dengan UndangUndang Nomor 25 Tahun 2009, Pasal 23 Ayat (5) menyebutkan bahwa penyelenggara berkewajiban menyediakan informasi kepada masyarakat secara terbuka dan mudah diakses. Lebih lanjut Permendagri Nomor 138 Tahun 2017, Pasal 22 Ayat (1) menyebutkan bahwa pengelolaan informasi wajib dilakukan secara terbuka dan mudah diakses oleh masyarakat. Kemudian Ayat (2) menyebutkan bahwa layanan informasi dapat dilakukan secara manual dan elektronik.

Hasil penelitian Bilyastuti (2012) menunjukkan bahwa adanya keterbukaan baik jenis layanan, biaya layanan, jadwal layanan, nama dokter atau petugas pemberi layanan, maupun alur dan persyaratan layanan, namun begitu masih banyak pasien yang belum paham alur pelayanan tersebut.

Hasil penelitian menunjukkan bahwa DPM PTSP Kabupaten mempublikasikan tatanan struktur organisasi, yakni struktur organisasi Bidang Pengaduan, Kebijakan, 
Pelaporan Pelayanan dan Bidang Pengendalian Pelaksanaan Penanaman Modal dan Informasi Penanaman Modal lengkap dengan nama-nama petugas yang berwenang, mekanisme/alur pelayanan visi ,misi, motto pelayanan, jenis layanan, jadwal layanan baik hari dan jam layanan, dan pegawai menggunakan tanda pengenal. Akan tetapi belum mempublikasikan struktur organisasi secara umum lengkap dengan nama-nama petugas yang berwenang, serta belum dipublikasikan biaya masing-masing jenis pelayanan pada ruang pelayanan, brosur, maupun pada website.

\section{Informasi Pelayanan}

Menurut Oliver dan Drewry (1996) mengemukakan bahwa Informasi (information) adalah publikasi informasi cara reguler mengenai target-target kinerja dan seberapa baik dapat dipenuhi. Sejalan dengan Permendagri Nomor 138 Tahun 2017, Pasal 26 ayat (1) menyebutkan bahwa penyuluhan kepada masyarakat paling sedikit meliputi: a) hak dan kewajiban pemerintah daerah dan masyarakat terhadap pelayanan perizinan dan non perizinan; b) manfaat perizinan dan non perizinan bagi masyarakat; c) jenis pelayanan; d) persyaratan dan mekanisme layanan perizinan dan non perizinan; dan e) waktu dan tempat pelayanan.

Hasil penelitian Bilyastuti (2012) menunjukkan bahwa target maupun hasil kinerja tidak dipublikasikan secara terbuka tapi hanya dimuat dalam buku laporan tahunan intern rumah sakit.

Hasil penelitian menujukkan bahwa DPM PTSP Kabupaten Gowa mempublikasikan informasi target kinerja dan capaian pelaksanaan kinerja dalam bentuk hardcopy LAKIP setiap tahunnya yang hanya dapat di akses secara terbatas oleh penerima layanan. Akan tetapi belum mempublikasikan informasi target kinerja dan capaian pelaksanaan kinerja pada papan informasi pelayanan dan secara daring melalui website.

\section{Non Diskriminasi Pelayanan}

Menurut Oliver dan Drewry (1996) mengemukakan bahwa non diskriminasi (non discrimination) adalah pelayanan tersedia bagi siapapun tanpa membedakan ras dan jenis kelamin, tulisan yang dicetak tidak menggunakan bahasa minoritas, dimana disesuaikan dengan kebutuhan. Tidak adanya perlakuan yang diskriminatif dalam memberikan pelayanan publik memang sudah seharusnya, karena semua warga negara memiliki hak asasi manusia 
yang sama. Hal ini ditegaskan dalam pasal 34 point (a) Undang-Undang Nomor 25 Tahun 2009 menyebutkan bahwa pelaksana dalam menyelenggarakan pelayanan publik harus berprilaku adil dan tidak diskriminatif.

Hasil penelitian Bilyastuti (2012) menunjukkan bahwa dalam pelayanannya semua pasien diperlakukan sama tanpa ada diskriminasi. Hasil penelitian menunjukkan bahwa DPM PTSP Kabupaten Gowa memberikan perlakukan pelayanan sesuai dengan standar pelayanan yang berlaku. Pelayanan yang diberikan berdasarkan standar pelayanan masing-masing jenis pelayanan sebagai bentuk jaminan kesamaan hak dan perlakukan adil bagi penerima layanan. Akan tetapi belum memiliki peraturan jaminan kesamaan hak bagi penerima layanan serta sanksi bagi pegawai yang tidak berlaku adil bagi penerima layanan.

\section{Daya Respon Pelayanan}

Menurut Oliver dan Drewry (1996) mengemukakan bahwa daya respon (responsivenness) adalah kepekaan yang tinggi terhadap kebutuhan konsumen; konsumen diminta pendapatnya mengenai pelayanan yang diberikan. Daya respon dalam pelayanan publik merupakan kepekaan atau kemampuan suatu organisasi penyelenggara pelayanan publik untuk menangkap apa yang menjadi keinginan atau kebutuhan masyarakat pengguna layanan, dan melakukan citizen's charter akan membuat pelayanan publik lebih responsif terhadap pengguna layanan.

Hasil penelitian Bilyastuti (2012) menunjukkan bahwa ada survei Indeks Kepuasan Masyarakat (IKM) sebagai bahan evaluasi untuk perbaikan pelayanan serta merespon dengan segera apa yang menjadi keluhan pasien. Hasil penelitian menunjukkan bahwa pegawai DPM PTSP Kabupaten Gowa cukup responsif dan peka terhadap penerima layanan dengan memberikan pelayanan sesuai dengan jenis pelayanan yang dibutuhkan serta memiliki kepekaan dan kemampuan untuk menyediakan prasarana pelayanan berupa ruangan pelayanan, loket informasi pelayanan, loket pengaduan, dan ruang tunggu pelayanan, ruang konsultasi pelayanan. Akan tetapi pegawai tidak meminta tanggapan terhadap penerima layanan.

\section{Keluhan Pelayanan}

Menurut Oliver dan Drewry (1996) mengemukakan bahwa keluhan (grievances) yaitu tingkat respon terhadap keluhankeluhan yang ada (termasuk mediator lokal yang terkait penanganan klaim-klaim minor) 
perbaikan yang memadai termasuk dengan kompensasi yang tepat. Sejalan dengan Undang-Undang Nomor 25 Tahun 2009, Pasal 36 Ayat (1) menyebutkan bahwa penyelenggara berkewajiban menyediakan sarana pengaduan dan menugaskan pelaksana yang kompeten dalam pengelolaan pengaduan. Lebih lanjut Permendagri Nomor 138 Tahun 2017, Pasal 20 Ayat (1) menyebutkan bahwa pengelolaan pengaduan masyarakat dilakukan secara cepat, tepat, tertib, tuntas, transparan, dan dapat dipertanggung-jawabkan.

Hasil penelitian Bilyastuti (2012) menunjukkan bahwa adanya jaminan kepastian penyelesaian masalah terhadap keluhan yang disampaikan, karena hal itu diatur dalam dokumen citizen's charter. Pelaksanaan adopsi citizen's charter belum optimal juga di lihat dari nilai Indeks Kepuasan Masyarakat (IKM) yang justru mengalami penurunan dibandingkan dengan tahun sebelum.

Hasil penelitian menujukkan bahwa DPM PTSP Kabupaten Gowa tanggap terhadap keluhan pelayanan yang ada dengan tersedianya sarana prasarana pelayanan pengaduan penerima layanan, yakni mekanisme pengaduan dan mekanisme pengelolaan pengaduan, sarana pengaduan melalui Telpon, E-Mail, SMS, Kotak Pengaduan, dan Pengaduan Langsung pada Loket
Pengaduan, ruang konsultasi pelayanan, serta jangka waktu pengaduan yang jelas. Akan tetapi belum menjalin kerjasama dengan lembaga independen yang berperan sebagai mediator apabila tidak mendapatkan kesepakatan dalam penyelesaian masalah atau keluhan penerima layanan.

\section{KESIMPULAN DAN SARAN}

DPM PTSP Kabupaten Gowa belum sepenuhnya menerapkan prinsip citizen's charter sebagaiamana teori Oliver dan Drewry, yakni standar pelayanan yang tinggi (higher standard), keterbukaan (openness) pelayanan, informasi (information) pelayanan, tidak diskriminasi (non discrimination) pelayanan, daya respon (responsiveness) pelayanan, keluhan (grievances) pelayanan, karena belum ada kerjasama dengan lembaga pengawasan independen dan tanda charter (petunjuk arah) pelayanan; belum ada publikasi struktur organisasi lengkap dengan namanama pejabat yang berwenang dan publikasi biaya pelayanan secara munual dan daring; belum ada publikasi informasi target kinerja dan capaian pelaksanaan kinerja secara daring; belum memiliki peraturan mengenai jaminan kesamaan hak bagi penerima layanan; belum adanya permintaan tanggapan penerima layanan oleh pegawai 
atas pelayanan yang diberikan; belum adanya kerjasama dengan lembaga independen sebagai mediator antara pihak DPM-PTSP Kabupaten Gowa dengan penerima layanan apabila tidak terjadi kesepakatan penyelesaian keluhan atau pengaduan.

Olehnya itu disarankan agar Kepala DPM PTSP Kabupaten Gowa melakukan kerjasama dengan lembaga pengawasan independen, mengadakan tanda charter (petunjuk arah) pelayanan; mempublikasikan struktur organisasi lengkap dengan nama-nama pejabat yang berwenang, biaya pelayanan secara munual dan daring, informasi target kinerja dan capaian pelaksanaan kinerja secara daring; membuat peraturan jaminan kesamaan hak bagi penerima layanan; meminta tanggapan penerima layanan, melakukan kerjasama dengan lembaga independen sebagai mediator apabila tidak terjadi kesepakatan penyelesaian keluhan atau pengaduan.
Bilyastuti, Mai Puspadyna. 2012. Adopsi Citizen’s Charter (Kontrak Pelayanan) Untuk Optimalisasi Pelayanan Publik (Studi Pada Instalasi Rawat Jalan (IRJ) RSU Dr. Saiful Anwar Malang). Jurnal Wacana 15 (3). p 51-61 (online).

Keputusan Bupati Gowa Nomor 189 Tahun 2011 tentang Pelimpahan Kewenangan Pengelolaan Perizinan pada Kantor Pelayanan Terpadu Kabupaten Gowa.

Oliver, D, dan Drewry, G. 1996. Public Service Reform Pinter, A Cassell Imprint, Wellington House. England: 125 Strand, London WC2R OBB.

Peraturan Menteri Dalam Negeri Republik Indonesia Nomor 138 Tahun 2017 Tentang Penyelenggaraan Pelayanan Terpadu Satu Pintu Daerah.

Peraturan Daerah Kabupaten Gowa Nomor 11 Tahun 2016 tentang Pembentukan dan Susunan Perangkat Daerah

Peraturan Bupati Gowa Nomor 60 Tahun 2017 tentang Kedudukan, Susunan Organisasi, Tugas dan Fungsi, serta Tata Kerja Dinas Penanaman Modal dan Pelayanan Terpadu Satu Pintu Kabupaten Gowa.

Undang-Undang Nomor 25 Tahun 2009 Tentang Pelayanan Publik.

\section{REFERENSI}


Renny Puteri Harapan Rani dkk/Jurnal Administrasi Negara, Volume 24 Nomor 1 (2018)/ 61-76 